\title{
表面波探査による既設補強土壁の S波速度の測定と評価
}

\author{
小笠原明信 1 ・川尻峻二 2 ・橋本聖 ${ }^{3} \cdot$ 川口貴之 ${ }^{4} \cdot$ 田中悠暉 1 -中村大 5 ・山下聡 6
}

\begin{abstract}
近年，線状構造物である補強土壁の効率的な現況把握手法として表面波探查の有用性が報告されている．今 後, 補強土壁の健全性評価手法として表面波探查を高度利用するためには, 補強土壁の変状程度と表面波探查 から取得できる $\mathrm{S}$ 波速度 $V_{\mathrm{S}}$ の関連性を把握する必要がある。そこで本研究では, 北海道オホーツク地域に施 工されている変状程度が異なる 5 つの補強土壁に対して表面波探査を行い， $V_{\mathrm{S}}$ の 2 次元分布と壁面パネルの傾 斜角の関連性について調べた，その結果，壁面パネル傾斜角が大きい場合には，深度増加に対して $V_{\mathrm{S}}$ は単調 に増加せず，局所的に低下しており，表面波探查から取得できる $V_{\mathrm{S}}$ を利用することで補強土壁の健全性を評 価できる可能性を見出した.
\end{abstract}

キーワード：既設補強土壁，健全性評価，S波速度，壁面傾斜角

\section{1.はじめに}

2013 年 6 月に国土交通省は，道路構造物の適切な維持 管理として【点検】 $\rightarrow$ 【診断】 $\rightarrow$ 【措置】 $\rightarrow$ 【記録】 $\rightarrow$ 【次回点検】のサイクルによって，䂆方的な保全を進め て長寿命化を図る必要があるという考え方を示した 1). コンクリート構造物や鋼構造物では, 非破壊検查手法と して超音波探査利用の研究開発が進み, 構造物のひび割 れや断面欠損箇所の検出等, 構造物の健全性を評価する 【点検・診断】手法が定着している。一方，一般盛土や 補強土壁を代表とする土構造物に着目すると，健全性の 指標を得ることができる実務的な【点検・診断】手法は 確立されていない，一般に土構造物ではコンクリート構 造物や鋼構造物とは異なり, 土構造物を構成する地盤材 料の物性がばらつきを有していることや，線状に長い構 造物であるため施工されている範囲の中で地形条件が異 なるなどの理由から, 土構造物内部の地盤性状を確認し て健全性を判定する必要がある.

以上のようなことから，目視検查などの点検結果か ら詳細な診断が必要となった際には，土構造物内の地盤 性状を把握するためにボーリングを行う。しかし, 線状 構造物である土構造物の地盤性状をボーリングによって 把握するためには，ボーリング本数を多くする必要があ り，これには多くの労力と費用が必要となる．そこで近 年では, 非破壊物理探査手法である表面波探查から取得
できる $\mathrm{S}$ 波速度 $V_{\mathrm{S}}$ の 2 次元分布（以下， $V_{\mathrm{S}}$ 分布とす る）を用いて補強土壁の性状把握を行った事例が報告さ れている2,3,4)。これらの事例では，補強土壁内部での局 所的な乾燥密度の低下領域や高含水比領域を $V_{\mathrm{S}}$ 分布の 相対的な大小関係によって把握できると報告されている。 このため, 表面波探査は補強土壁の性状を非破壊て把握 できる有用なツールの一つであると認識されつつある. よって, 今後は表面波探査を用いて補強土壁の機能低下 の有無を判断できるような，実効性の高い健全性評価手 法の確立が期待されるが，そのためには健全および不健 全な補強土壁に対して系統的に表面波探査を実施し，変 状後もしくは今後変状が発生すると予想される補強土壁 を抽出できるような， $V_{\mathrm{S}}$ を基本的なパラメータとした 健全性指標について検討寸る必要がある.

そこで本研究では, 壁面パネルの変状程度と補強土 壁内部の $V_{\mathrm{S}}$ 分布の関連性を把握するため，鋼製または ジオシンセティックス製の帯状補強材を用いている変状 程度の異なる 5 つ既設補強土壁に対し，表面波探査を 実施した．さらに，補強土壁の裏込め土におけるすべり 線発生の有無を間接的に評価可能な健全性指標の一つと して，壁面パネルの傾斜角 5り着目し， $V_{\mathrm{S}}$ 分布と壁面パ ネル傾斜角の空間分布を比較した. また, 深度方向の $V_{\mathrm{S}}$ の変化や, 補強土壁内の $V_{\mathrm{S}}$ の頻度分布等を考察する ことで， $V_{\mathrm{S}}$ をパラメータとした補強土壁の健全性評価 指標について検討した.

1地盤工学会員, 北見工業大学大学院工学研究科 社会環境工学専攻（广090-8507 北見市公園町165番地）

${ }^{2}$ IGS個人会員, 北見工業大学 工学部 助教（T090-8507 北見市公園町165番地）

3地盤工学会員, 寒地土木研究所 寒地地盤チーム（干062-8602札幌市豊平区平岸1条3丁目1番34号)

${ }^{4}$ IGS個人会員，北見工業大学 工学部 准教授（下090-8507 北見市公園町165番地）

3地盤工学会員, 北見工業大学 工学部 准教授（广090-8507 北見市公園町165番地）

5地盤工学会員, 北見工業大学 工学部 教授（广090-8507 北見市公園町165番地） 


\section{2. 調査箇所および現地試験結果}

\section{（1）調査方法の概要}

調査対象の補強土壁は，北海道東部のオホーツク地域 内に立地している5地点である。これら5地点のうち4地 点は鋼製帯状補強材を，1地点はジオシンセティックス 製帯状補強材を利用した補強土壁である。調查内容は補 強土壁天端での表面波探査と壁面傾斜の計測である.

図一 1 は本研究で実施した表面波探査の原理を概略的 に示したものであるの. 表面波探査は地盤の地表付近を 伝わる表面波（レイリー波）を測定・解析することで地 盤のS波速度を求めることができる調查方法である。八 ンマーやかけや等で人工的に地表面を起振すると表面波 が発生する.この表面波の時間領域の波形記録をフーリ 工解析することで周波数と位相速度の関係を算出し，す べての地震計での結果を重ね合わせることで位相速度と 周波数の関係である分散曲線が取得できる. 一般的に表 面波は，その周波数によって伝播する深度が異なり，高 周波数の波は浅い地盤を，低周波数の波は深い地盤を反 映している. 経験的に波長の3分の 1 深さに相当すると いう関係を利用して解析の初期モデルを作成し，波形記 録から算出した分散曲線を最も良く再現するS波速度構 造を逆解析によって推定する。この解析を各地震計での 分散曲線に応じて行い, 各地震計で得られたS波速度構 造を測線方向に補間して $V_{\mathrm{S}}$ の2次元分布が取得できる. 地盤剛性を表すせん断剛性は， $V_{\mathrm{S}}$ の二乗に比例するため, $V_{\mathrm{S}}$ の増減は地盤剛性の大小を間接的に表す。また，本研 究で実施した表面波探査は，対象地盤を深さ方向と測線 方向の2次元問題として取り扱い（測線直角方向の地盤 性状は一様であると仮定），測線鉛直方向の物性や応力 状態を反映した $V_{\mathrm{S}}$ 分布を取得している. この表面波探査 の補強土壁への適用を考えると, 壁面パネルの変状など によって測線鉛直方向の地盤での応力や密度変化が発生 している場合には，これらの影響がV分布に反映される。 このような表面波探査を補強土壁に実施した過去の事例

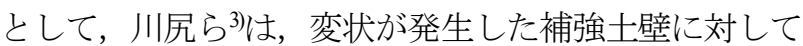
表面波探查を行い， $V_{\mathrm{S}}$ 分布の相対的な低速度領域は壁面 パネルの変状箇所と概ね一致し，N值や乾燥密度 $\rho \mathrm{d}$ が相 対的に小さい脆弱層を表面波探査によって把握できたと している。. また，中村ら ${ }^{4}$ は変状した補強土壁の撤去時 に行った含水比や密度の測定の結果と表面波探査による 補強土壁横断面の $V_{\mathrm{S}}$ 分布を比較した結果，含水比が高く， 乾燥密度が低い領域と $V_{\mathrm{S}}$ の低速度領域が概ね一致したと 報告している．上記の事例から $V_{\mathrm{S}}$ 分布によって補強土壁 の壁面パネルの変状に応じた内部構造の変化を非破壊で

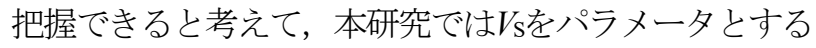
ことで補強土壁の健全性を評価可能であると判断した.

写真一 1 は本研究における表面波探查の実施例を示し ている。.すべての補強土壁で壁面パネルから $1 \mathrm{~m}$ 程度離 れた位置に表面波探査の測線を設けた。ここで川尻ら》 は，表面波探查で通常用いられる木製かけやよりも高周
波の表面波を発生可能な金属ハンマーと金属プレートを 用いた起振方法を提案しており，本研究においてもこの 手法を用いた．地震計の設置間隔は $1 \mathrm{~m}$ とたため，精 度が保証される探査深度は概ね10mである。

次に，壁面パネルの傾斜角について，Izawa \& Kuwano ${ }^{5)}$ は補強土壁模型に対する遠心載荷実験加，裹込め土に 発生するせん断ひずみと壁面の傾きの関係式を求めてい る.この関係式より, 裏込め土のピーク強度発揮時の最 大せん断ひずみが室内試験によって既知の場合には，裏 込め土での寸べり線発生の有無を壁面傾斜角から推定可 能であり，地震後の補強土壁の簡易な損傷度評価法とし て提案している. 本研究では, 上記の研究成果を参考に 壁面パネルの傾斜角は，表面的に補強土壁の損傷度や健 全性を評価できる指標と位置付けて，表面波探査の実施 に併せて計測を行った. 図一2 は本研究で計測した壁面 パネル傾斜角 $\theta 0$ 定義を示している，壁面が仰角状態を 正とし，俯角状態を負とした。 $\theta$ はデジタル角度計を用 いて小数点以下 2 桁まで読み取った.

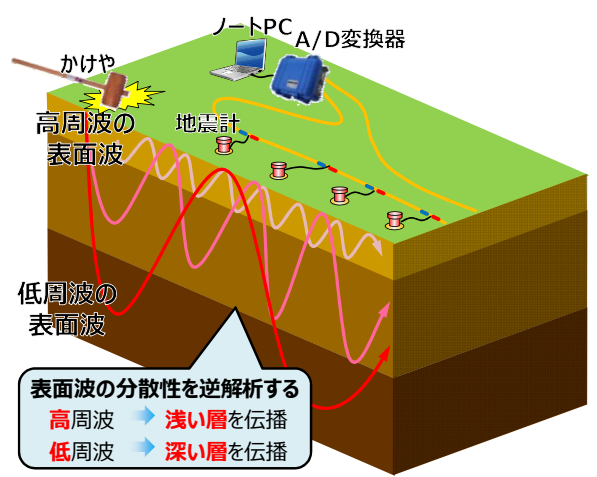

図-1 表面波探査の概念図 9

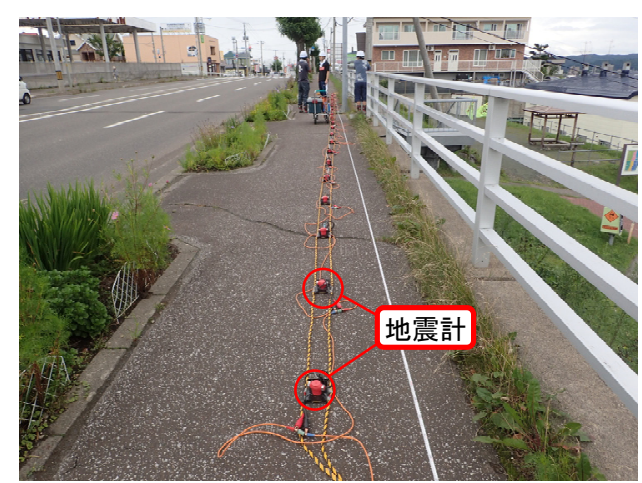

写真-1＼cjkstart表面波探查の測線の例

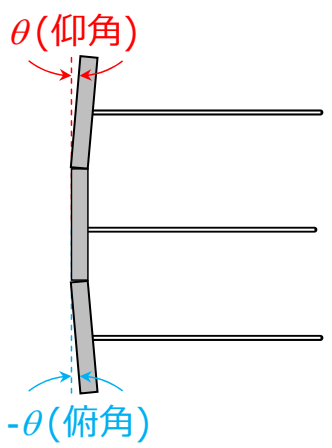

図-2＼cjkstart壁面パネルの仰角之俯角の定義 


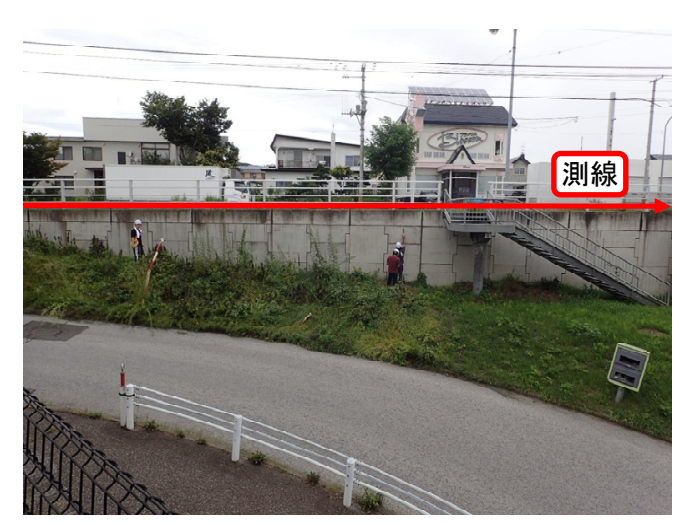

写真-2 調查箇所(1)の全景と表面波探査測線

\section{(1) 調査箇所(1)}

写真一 2 は調査箇所(1)の補強土壁の全景および表面波 探査を行った測線の状況を示している. 当該補強土壁の 補強材は鋼製の帯状補強材であり, 最大壁高 $3.0 \mathrm{~m}$, 延長 $31.5 \mathrm{~m}$ ，壁面寸法 $1.5 \mathrm{~m} \times 1.5 \mathrm{~m}$ ，笠コンクリート厚は約 0.5 0.8mである. 1982年に竣工した当該補強土壁は道路 盛土に腹付けされている. 現地踏査では，壁面パネルに は隅角部での圧縮破壊などの損傷や変状は確認できなか った. また，笠コンクリートにおいても目立ったクラッ クなども無く, 現在, 供用中の歩道および道路ともに有 害な沈下は確認されていない。

図一 3 a) は当該補強土壁の $\theta$, b) 情面波探査から取 得したV分の布を示したものである.ここで， $\theta$ の分布 については, 各壁面パネルで計測しているため, 実際に は図ー3a)に示した滑らかなコンター図のように $\theta$ は分 布していない。しかし， $\theta$ の増減を伴う壁面パネルの変 状によって裏込め土では，ある影響範囲を持って応力状 態が変化すると予想される. このような理由から本検討 では, 補強土壁の応力状態の変化を $\theta$ の増減で間接的に 表現できると仮定した．また， $\theta$ の比較対象となる $V_{\mathrm{S}}$ 分 布は2次元のコンター図で表現される. 以上のようなこ とを考慮して，本文では $\theta$ の分布をコンター図で表し， $V_{\mathrm{S}}$ 分布との比較を試みた. $\theta$ の分布に着目すると, 補強 土壁下部で俯角状態となっているものの，すべての箇所 で $\theta$ は $1^{\circ}$ 以内である. なお，壁面パネル傾斜角の最大值 $\theta_{\text {max }}$ は $X=30 \mathrm{~m}$ 付近の箇所であり, $\theta_{\text {max }}=0.6^{\circ}$ であった. 次 に $V_{\mathrm{S}}$ 分布を見ると, 最下部の壁面パネル付近を境界した 下方では $V_{\mathrm{S}}=240 \mathrm{~m} / \mathrm{s}$ 以上であり，支持地盤に相当してい ると推察されるため, 表面波探査から取得できる $V_{\mathrm{S}}$ 分布 によって補強土壁周辺および補強土壁内の地盤性状を把 握できると判断できる．補強土壁の $V_{\mathrm{s}}$ は， $V_{\mathrm{S}}=200 \mathrm{~m} / \mathrm{s}$ 以 下の範囲で分布しており, 補強土壁の上部から下部に向 かって $V_{\mathrm{S}}$ 増加する傾向にある. また， $V_{\mathrm{S}}$ の局所的な低 下領域など確認できず，比較的一様な状態にある.

\section{(2) 調査䇢所(2)}

写真－3および写真－4は，それぞれ調査箇所(2)-1と 調查箇所(2)-2における補強土壁の全景と表面波探查の測 線を示している. 調査箇所(2)で対象とする補強土壁は,

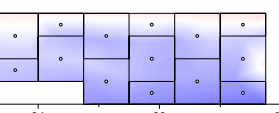

$\mathrm{S}$ 波速度, $v_{\mathrm{s}}(\mathrm{m} / \mathrm{s})$

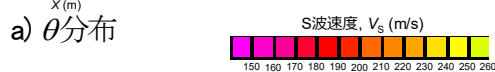

$V_{\mathrm{s}}=170 \mathrm{~m} / \mathrm{s}$

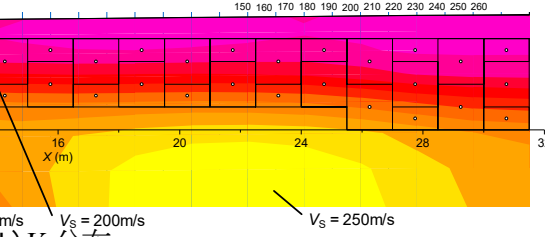

b) $V_{\mathrm{S}}$ 分布

図-3 調査䇢所(1)の $\theta$ および $V_{\mathrm{S}}$ 分布

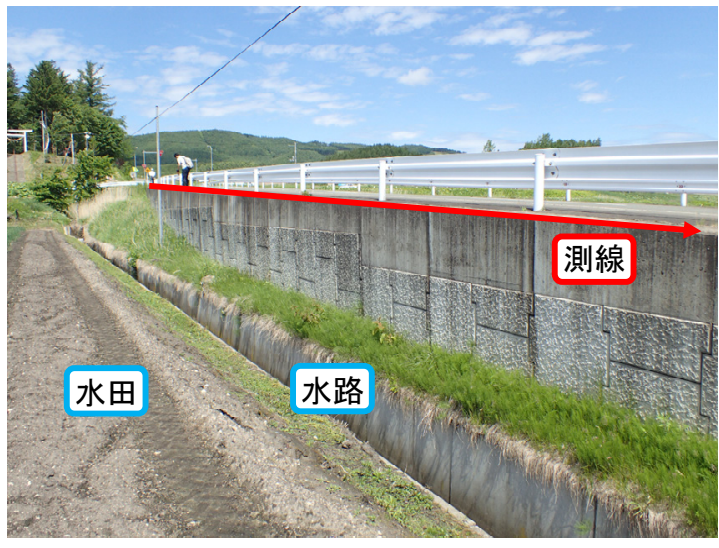

写真-3 調查箇所(2)-1 の全景と表面波探査測線

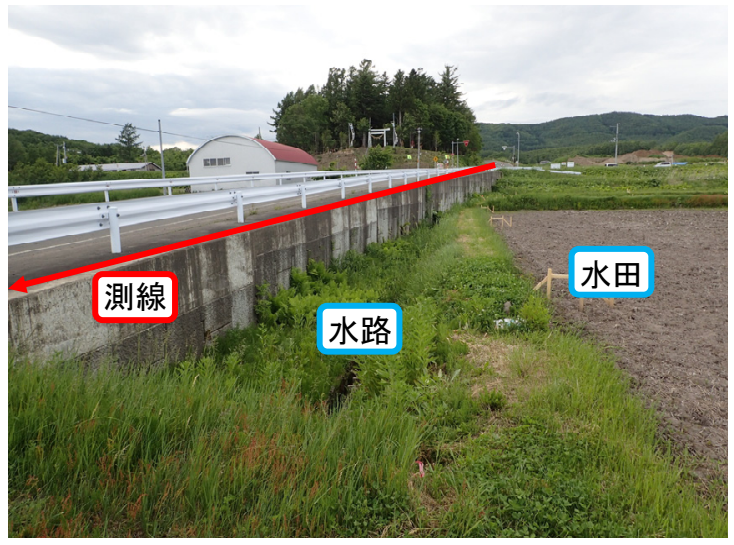

写真-4 調查箇所(2-2 の全景と表面波探查測線

丘陵地の裙野から広がる水田内に構筑されている道路盛 土の両側に施工されている. また，当該補強土壁は道路 延長方向に傾斜している支持地盤上に施工されている. 補強土壁に関する一般図等が無いため詳細は不明ではあ るが，壁面パネル位置関係が道路左右で一致していない ため, 道路両側の壁面パネルは補強材に連結されていな いと予想される. このため, 調査箇所(2)-1 調査箇所(2) 一2では，それぞれ独立した補強土壁であると判断した。 なお，竣工した年代は不明である．調査箇所(2)-1の補強 土壁は，最大壁高 $4.41 \mathrm{~m}$ ，延長 $91.14 \mathrm{~m}$ ，壁面寸法 $0.98 \times$ $0.98 \mathrm{~m}$ ，笠コンクリート厚は約 $0.44 \sim 0.93 \mathrm{~m}$ である。調査 箇所(2)-2の補強土壁は, 最大壁高4.9m, 延長89.18m, 壁 


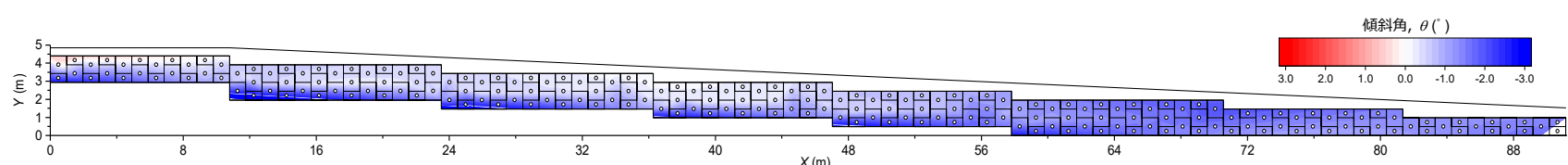

a) $\stackrel{x(m)}{\theta}$ 分布

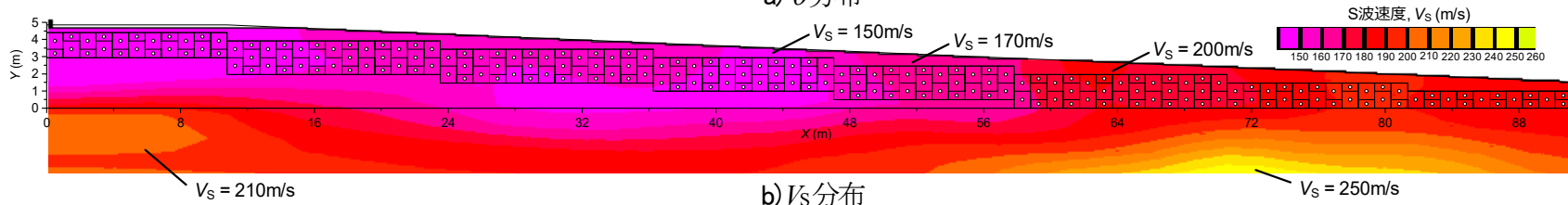

図-4 調查箇所(2)-1 の $\theta$ および $V_{\mathrm{S}}$ 分布

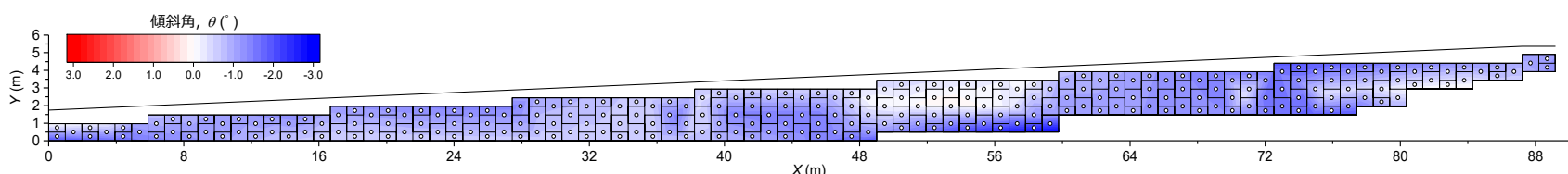

a) $\theta$ 分布

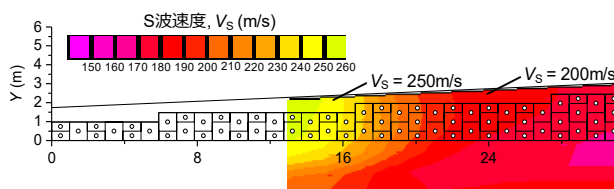

$v_{\mathrm{s}}=170 \mathrm{~m} / \mathrm{s}$

$V_{\mathrm{S}}=150 \mathrm{~m} / \mathrm{s}$

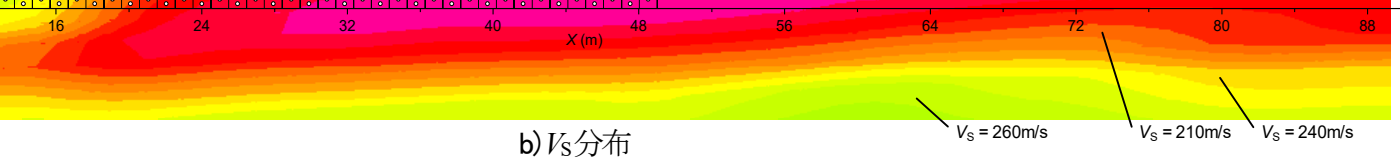

図-5 調查箇所(2)-2 の $\theta$ および $V_{\mathrm{S}}$ 分布

面寸法 $0.98 \times 0.98 \mathrm{~m}$ ，笠コンクリート厚約 $0.47 \sim 0.76 \mathrm{~m}$ であ る. なお，両補強土壁ともに壁面パネルの欠損などの目 立った損傷は確認できなかった。 しかし，一部の箇所で は，天端に近い壁面パネルが水路側に前傾している状態 が目視でも確認できた.

図一 4a) は調查箇所(2)-1における $\theta$, b) は $V_{S}$ 分布を示 している. また，図一5a) は調査箇所(2)-2における $\theta$, b) は $V_{\mathrm{S}}$ 分布を示している。両補強土壁ともに $\theta$ は，ほぼ すべての計測地点で俯角状態となっている. 調查箇所(2) -1では $X=56 \mathrm{~m}$ 以降のすべての壁面パネルで，調查箇所 (2)-2では $X=60 \sim 80 \mathrm{~m} の$ 範囲で天端に近い壁面パネルが俯 角であるため補強土壁全体が前傾した状態にある。なお， $\theta_{\max }$ は調查箇所(2)-1では $\theta_{\max }=2.6^{\circ}$ となり, 調查箇所(2)-2 では $\theta_{\max }=2.9^{\circ}$ であった. $V_{\mathrm{S}}$ 分布を見ると, 補強土壁より も支持地盤の $V_{\mathrm{S}}$ は大きい值を示しているものの, 調査䇢 所(1)と比較すると切盛境界を明瞭に判断することはでき ない。ここで，田中ら ${ }^{8}$ は記録的な降雨履歴を受けた試 験盛土に対寸る表面波探査の結果から，雨水浸透後には 盛土内の $V_{\mathrm{S}}$ が低下寸ると報告している。 この結果を勘案 すると，調査箇所(2)における水路と補強土壁下部パネル 間のステップ部の地盤は湿潤した状態にあったことから， 補強土壁周辺では水田のため支持地盤内の地下水位が高 いと予想される.これによって補強土壁の裏込め土の含 水比も比較的高いために $V_{\mathrm{S}}$ 方低速度状態となり, 補強土 壁と支持地盤を比較した場合の $V_{\mathrm{S}} に$ 明瞭な差が表れなか った可能性がある. しかし，調查箇所(2)-2における $X=$ $15 \mathrm{~m}$ 付近では $V_{\mathrm{S}}$ 局所的な高速度領域は確認できるもの の，全体的な傾向としては調査箇所(2)-1および(2)-2の補 強土壁内において局所的かつ著しくV、゙低下している領

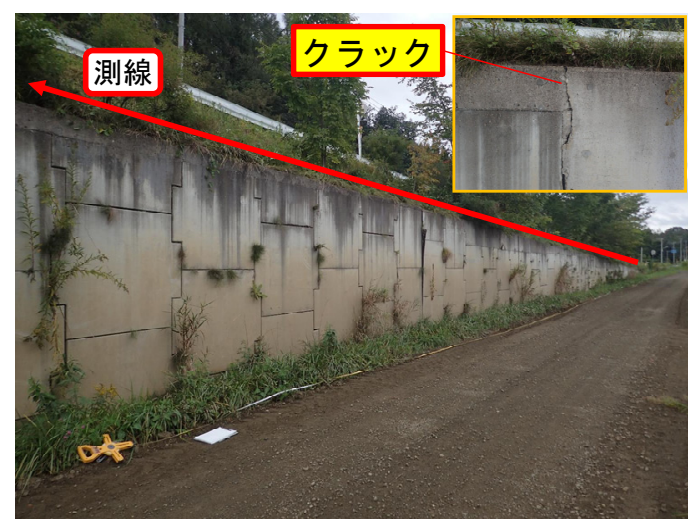

写真-5 調査箇所(3)の全景と表面波探査測線

域は確認できない。

\section{(3) 調査箇所(3)}

写真一 5 は調査箇所(3)の補強土壁の全景と表面波探査 の測線の状況を示している．当該補強土壁では鋼製の帯 状補強材が用いられており，最大壁高 $3.0 \mathrm{~m}$ ，延長 $78 \mathrm{~m}$, 壁面寸法 $1.5 \times 1.5 \mathrm{~m}$ ，笠コンクリート厚約 $0.4 \sim 0.7 \mathrm{~m}$ である. 1979年に竣工した当該補強土壁は，丘陵地の裙野に片切 片盛土で構築された道路盛土における補強土壁である。 天端部には灌木が生育しており，壁面パネルの境界部か らは草本が生育していた，さらに一部の壁面パネルや笠 コンクリートではクラックが発生していた.

図一 6a) は調查箇所(3)における $\theta$, b) は $V_{\mathrm{S}}$ 分布を示し ている。なお，当該補強土壁では，上述した天端部での 灌木の植生の影響で表面波探査の測線が確保できなかっ たため, $\theta$ と $V_{\mathrm{S}}$ 分布の計測範囲は一致していない， $\theta$ 計 


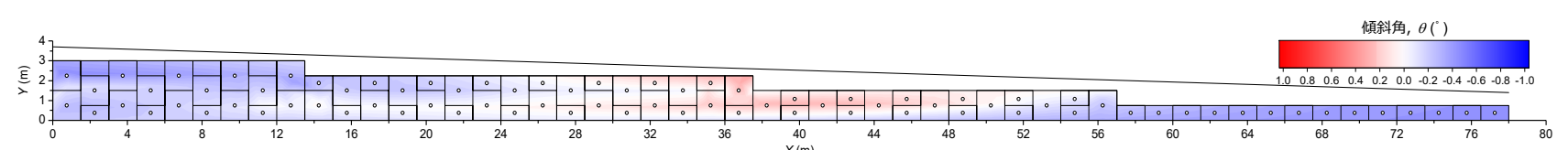

a) $\stackrel{x(m)}{\theta}$ 男布

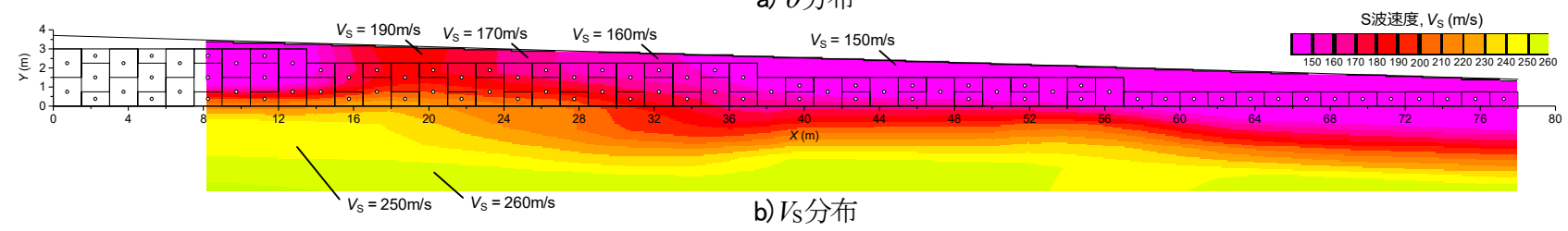

図-6 調查箇所(3)の $\theta$ および $V_{\mathrm{S}}$ 分布

測結果は, $X=0 \sim 20 \mathrm{~m}$ 範囲および $X=60 \mathrm{~m}$ 以降では $\theta=1^{\circ}$ 程度の俯角状態にある. 一方, $X=24 \sim 48 \mathrm{~m} の$ 範囲 では $\theta=-1^{\circ}$ 程度の仰角状態となっている. 次に補強土壁 の $V_{\mathrm{s}}$ は， $X=16 \sim 24 \mathrm{~m}$ 範囲を除くと， $V_{\mathrm{s}}=170 \mathrm{~m} / \mathrm{s}$ 以下の 範囲で一様に分布している. $X=16 \sim 24 \mathrm{~m}$ 範囲では, 補 強土壁天端の灌木生育が密であり，他の箇所と比較する と地震計の据え付けがやや不安定であったため，当該箇 所では測定誤差が含まれている可能がある．なお，支持 地盤のV $\mathrm{s}$ は補強土壁内と比較して高速度状態となってお り，補強土壁と地山境界を比較的明瞭に判断できる.

\section{(4) 調査箇所(4)}

写真－6a),b) は調査箇所(4)の補強土壁における壁面 パネルの変状状況を示したものである. 当該補強土壁の 補強材にはジオシンセティック製の帯状補強材が用いら れており，最大壁高9.6m，延長 $359.1 \mathrm{~m}$ ，壁面寸法 $1.2 \times$ $2.7 \mathrm{~m}$ である，当該補強土壁では，2016年の竣工後に施工 管理值内であった壁面パネルの一部が，融雪期に写真一 6a),b)に示すように壁面パネルの変状と水平変位が進 行し，施工管理值である壁高 $H の 3 \%(0.03 H)^{9)}$ を超過した。 このため，現在では変状した壁面パネルを撤去し，排水 設備を強化した上で再構築が行われている，当該補強土 壁では補強土壁の施工延長が長いため，壁高が低く変状 が顕著な領域（以下，A地点），壁高が高く変状が顕著 な領域（以下， B地点）, 変状が認められない領域 (C 地点）の3つの地点に調査地点を分けて，表面波探査お よび壁面の傾斜の測定を行った. 図ー7a)およびb)はA 地点, 図一8a)および) はB地点, 図一 -9a)および) はC 地点における $\theta$ と $V_{\mathrm{S}}$ 分布を示している。 なお，AおよびB 地点において壁面パネルの水平変位が施工管理值を超過 している. $\theta$ の傾向として，A地点では補強土壁上部の 天端に近い壁面パネルは $\theta=7^{\circ}$ 程度の仰角状態となって おり, 補強土壁下部の壁面パネルは $\theta=-7$ 程度の俯角状 態であるため, 壁面パネルの全体的な形状としては $「 く 」 の$ 字状に変状している (写真一 $6 a$ a) 参照). B地 点では, A地点よりも $\theta$ は小さいものの, 天端に近い上 部の壁面パネルでは $\theta=5^{\circ}$ 程度の仰角状態にあり，その 下方の $Y=3 \sim 5 \mathrm{~m}$ の範囲では $\theta=-3^{\circ}$ 程度の俯角状態となっ ている.さらに，その下方の支持地盤に近い壁面パネル においても $\theta=-3^{\circ}$ 程度であり, B地点ではA地点と同様 に補強土壁の壁面パネルは「く」の字状を呈しているも

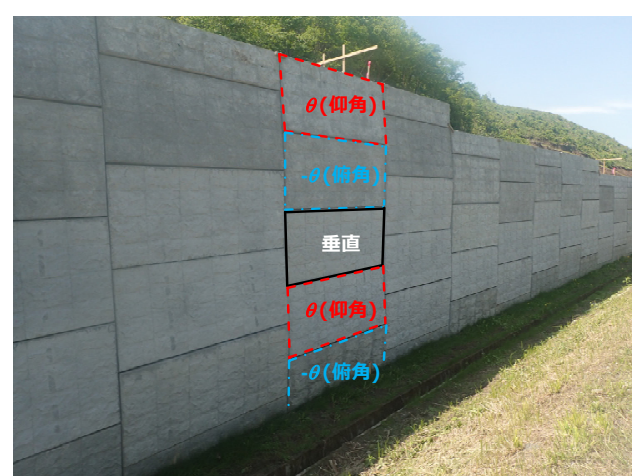

a）壁面パネルの変状状態の例

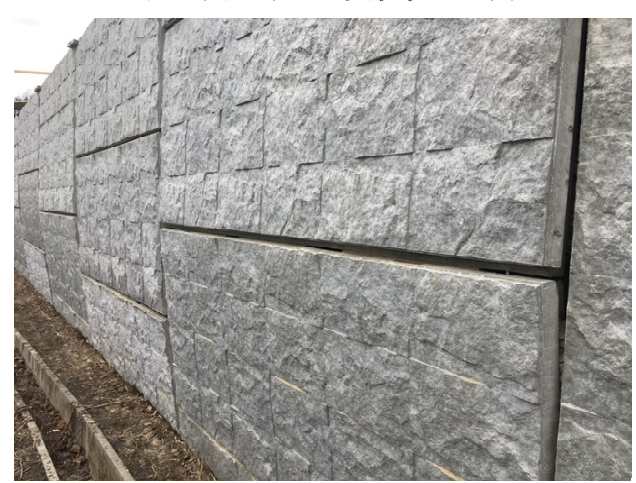

b) 図-7a)の $X=20 \mathrm{~m}$ 付近

写真-6 調查箇所(4)の壁面パネルの状況

のの，支持地盤から $2 / 3$ 程度の高さまでは前傾した状態 であり，天端に近い上部 $1 / 3$ 壁面パネルは後傾してい る. 次にC地点の $\theta$ は，全体的にはA地点およびB地点よ りも小さい. しかし，A地点およびB地点と同様に補強 土壁の天端付近の壁面パネルは仰角状態となり壁面パネ ルが後傾し，支持地盤に近い壁面パネルは俯角状態とな って壁面パネルは前傾して，補強土壁全体の変状モード としては「く」の字状態である，補強土壁内の $V_{\mathrm{s}}$ 分布 については， $\theta$ が最も大きく壁面パネルの変状が顕著な A地点の $Y=2 \sim 3.5 \mathrm{~m} の$ 範囲では $V_{\mathrm{s}}=150 \mathrm{~m} / \mathrm{s}$ 以下となってお り，この領域の $V_{\mathrm{s}}$ は上下の領域よりも低速度状態となっ ている. 一方で，B地点およびC地点の $V_{\mathrm{S}}$ な， $V_{\mathrm{S}}=200$ $300 \mathrm{~m} / \mathrm{s}$ 程度の範囲で分布しており, 深度方向に増加寸る 傾向にある．すなわち，施工管理值を大幅に超過する壁 面パネルの変状が確認された領域では，VSの局所的な低 速度領域が確認できた。 なお，すべての調査地点で支持 地盤のVSは補強土壁内よりも大きいため，当該箇所にお 


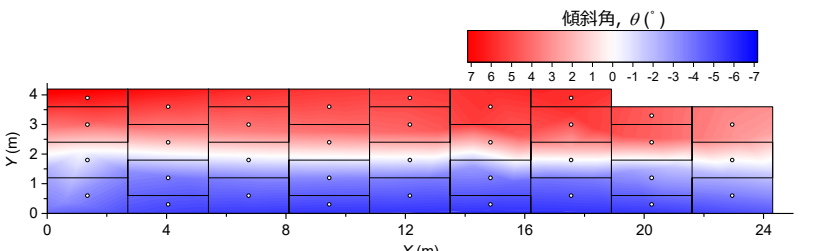

a) $\theta$ 分布

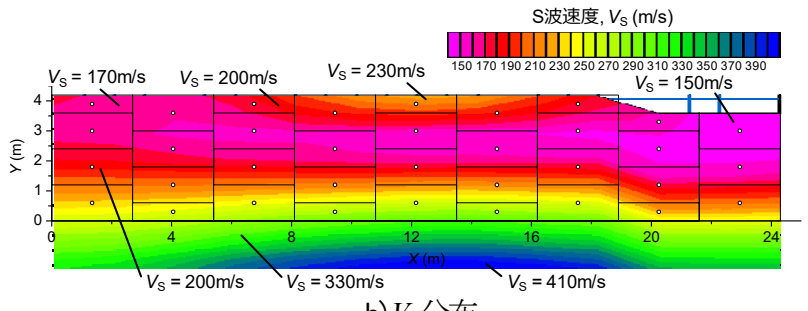

b) $V_{\mathrm{S}}$ 分布

図-7 A 地点における $\theta$ と $V_{\mathrm{S}}$ 分布

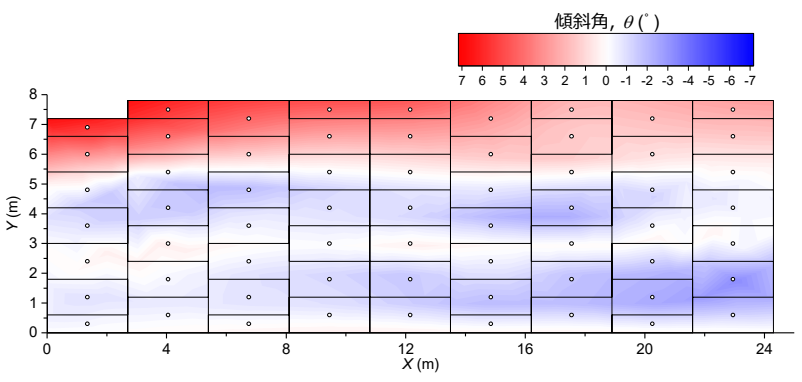

a) $\theta$ 分布

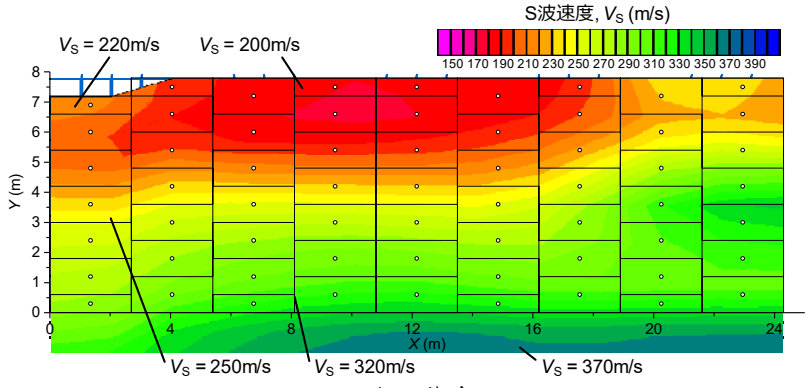

b) $V_{\mathrm{S}}$ 分布

図-8 B地点における $\theta$ と $V_{\mathrm{S}}$ 分布

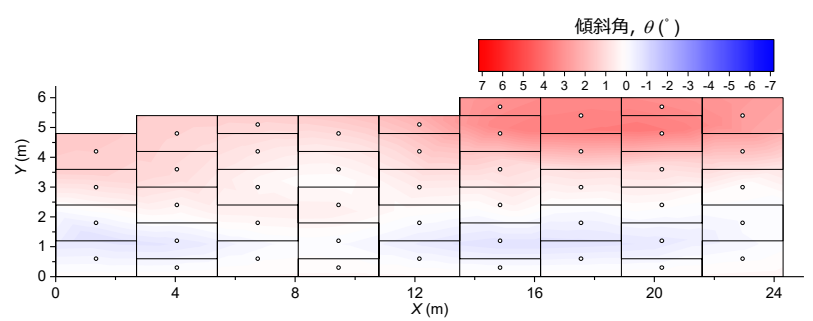

a) $\theta$ 分布 $\quad \mathrm{s}$ 波速度, $v_{\mathrm{s}}(\mathrm{m} / \mathrm{s})$

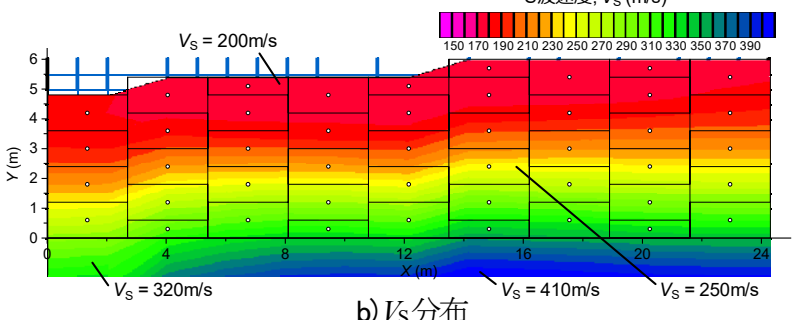

図-9 C地点における $\theta$ と $V_{\mathrm{S}}$ 分布

いても盛土と地山の境界を $V$ 分布から判断できる.

\section{Vsをパラメータとした健全性評価指標の検討}

図一10は，各調査箇所における補強土壁領域内の $V_{\mathrm{S}}$ の測線方向の平均值である $V_{\mathrm{sxa}}$ と補強土壁の天端を 0 と した時の深度の平均值 $z_{\mathrm{ave}}$ の関係である.ここで既往の 研究成果として, 細粒分質碩質砂に対して実施した室内 土質試験から $V_{\mathrm{S}}$ は, 拘束圧の大小によって増減するこ とが報告されている ${ }^{10)}$ ．また，原位置における $V_{\mathrm{S}}$ の簡 易な推定式として深度をパラメータとした経験式が提案 されている ${ }^{11)}$.このようなことから，V V 度（上載圧）ともに増加するパラメータである. 調查箇 所(1) (3)では， $V_{\text {Save }}$ は概衫深度とともに増加する傾向に ある．なお，調查箇所(2)では先述したように補強土壁の 周囲の地下水位が高く, 補強土壁領域内の含水比が高い
$\mathrm{S}$ 波速度の平均値, $V_{\mathrm{s} \times \mathrm{x}}(\mathrm{m} / \mathrm{s})$

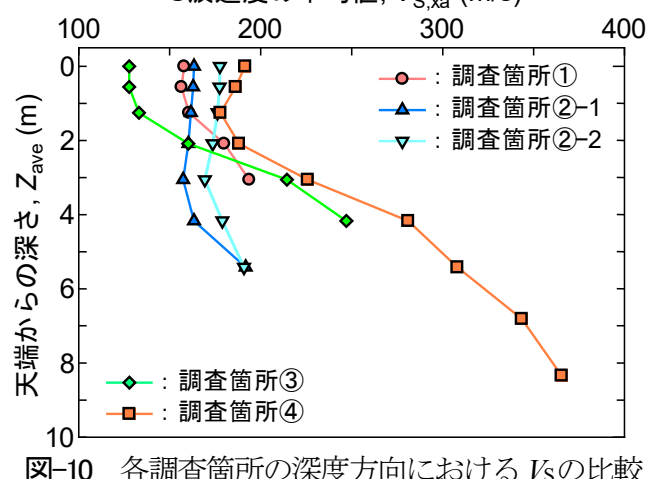

状態にあるため, $z_{\text {ave }}=3 \mathrm{~m}$ 程度で $V_{\mathrm{S}}$ がやや低下している と予想される，一方で，壁面パネルの変状が顕著であつ た調査箇所(4)では， $z_{\text {ave }}=1.5 \mathrm{~m}$ 程度で他の結果と比較し て明瞭に $V_{\text {Save }}$ が低下していることがわかる。この結果 から，補強土壁の変状程度と深度方向の $V_{\mathrm{S}}$ 分布には関 連性があり，定期的に深度方向の $V_{\mathrm{S}}$ の変化を計測して 
表-1 各調査箇所のおける $V_{\mathrm{S}}$ と $\theta$ に関するパラメータのまとめ

\begin{tabular}{|c|c|c|c|c|c|}
\hline 調査箇所 & $\begin{array}{l}\text { 補強土壁内における } \\
V_{\mathrm{S}} \text { の最小值, } V_{\mathrm{S} m \mathrm{~m}}(\mathrm{~m} / \mathrm{s}) \\
\end{array}$ & $\begin{array}{l}\text { 補強土壁内における } \\
V_{\mathrm{S}} \text { の最大値, } V_{\mathrm{S} \operatorname{mx}}(\mathrm{m} / \mathrm{s}) \\
\end{array}$ & $\begin{array}{l}\text { 補強土壁内における } \\
V_{\mathrm{S}} \text { の平均值, } V_{\mathrm{Sa}}(\mathrm{m} / \mathrm{s}) \\
\end{array}$ & $\begin{array}{l}\text { 最大壁面パネル } \\
\text { 傾斜角, } \theta_{\max }(\mathrm{C}) \\
\end{array}$ & $\begin{array}{l}\text { 平均壁面パネル } \\
\text { 傾斜角, } \theta_{\mathrm{ave}}\left({ }^{\circ}\right) \\
\end{array}$ \\
\hline (1) & 140 & 204 & 168 & 0.6 & 0.2 \\
\hline (2) -1 & 120 & 215 & 162 & 2.6 & 0.7 \\
\hline (2) -2 & 138 & 254 & 175 & 2.9 & 0.8 \\
\hline (3) & 98 & 208 & 148 & 1.0 & -0.3 \\
\hline (4) & 129 & 428 & 239 & 6.8 & 2.8 \\
\hline
\end{tabular}

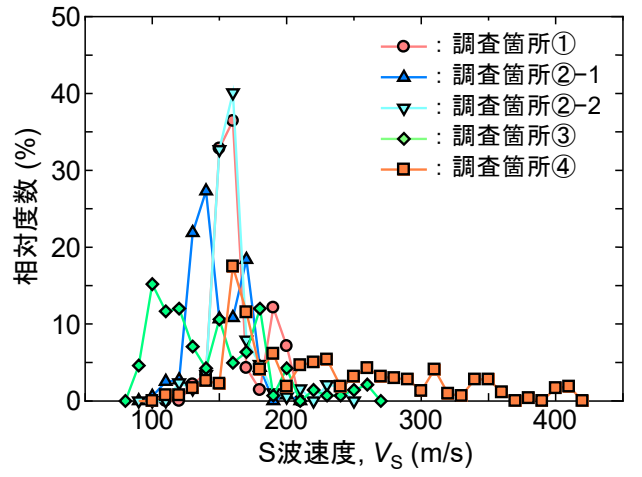

図-11 各調査箇所における $V_{\mathrm{S}}$ の頻度分布

比較することで，補強土壁の経時的な性能の変化を把握 できる可能性がある.

表一1は，本研究において補強土壁の損傷度を評価す るために検討した $V_{\mathrm{S}}$ および $\theta$ に関するパラメータのまと めである，なお， $\theta_{\max }$ は絶対值である．本研究では，経 時変化による損傷度が大きい補強土壁や施工時の締固め 不良による初期健全性の低い補強土壁では，補強土壁内 の裹込め土の物性や力学的性質にバラツキが生じている と考え，以下では $V_{\mathrm{S}} や \theta$ 以バラッキに関する簡易な評価 項目について検討した。

図－11は，各調査箇所における補強土壁内の $V_{\mathrm{S}}$ の頻 度分布を比較したものである．比較的 $\theta$ が小さく，損傷 度が低いと考えられる調査箇所(1)と(2)では，特定の $V_{\mathrm{S}}$ で相対度数が顕著に大きく， $V_{\mathrm{S}}$ は概ね正規分布の形状 を呈している．一方，壁面パネル境界部からの植生が繁 茂し，壁面パネルや笠コンクリートにクラックが発生し ていた調査箇所(3)では， $V_{\mathrm{S}}=100 \mathrm{~m} / \mathrm{s}$ で相対度数にピーク は確認できるものの，相対度数は調査箇所(1)，(2)と比較 すると小さい. また， $V_{\mathrm{S}}$ の最大值と最小值の差が大き く，正規分布の形状ではないことがわかる，さらに，施 工管理值を超える変状が発生した調査箇所(4)では，他の 調査箇所と比較して壁高が高く，上載圧が大きいため $V_{\mathrm{S}}=300 \mathrm{~m} / \mathrm{s}$ 以上の結果が計測されているものの， $V_{\mathrm{S}}$ の相 対度数のピークは $V_{\mathrm{S} \text { min }}=129.4 \mathrm{~m} / \mathrm{s}$ に近い $V_{\mathrm{S}}=160 \mathrm{~m} / \mathrm{s}$ であ り，調査箇所(1)，(2)とは相対度数の傾向が異なり，正規 分布の形状とはなっていない。この結果から，竕工直後 の補強土壁や，経年後も壁面パネルの変位が少ない健全 性が高い補強土壁では， $V_{\mathrm{S}}$ のばらつきは正規分布に近 $く, V_{\mathrm{S}}$ の最小值と最大值の差が比較的小さい状態にあ ると考えられる。一方，施工時の転圧不良等による初期 不良や竣工後の外力の作用によって変状が発生した補強 土壁では， $V_{\mathrm{S}}$ のばらつきは正規分布ではなく， $V_{\mathrm{S}}$ の相 対度数に複数のピークが存在する分布形状になっている

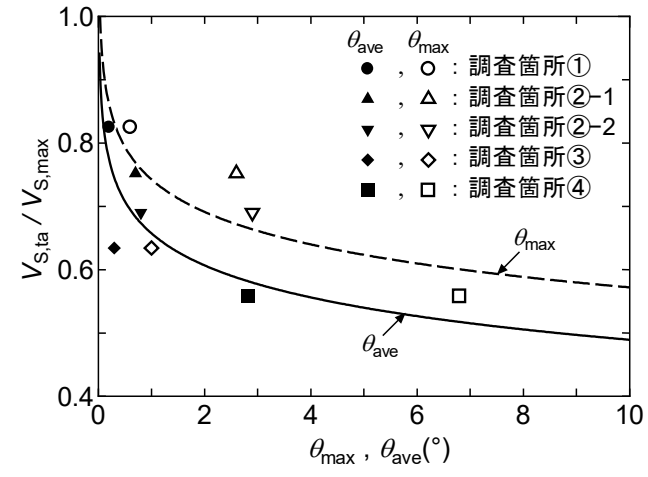

図-12 各調査箇所における $V_{\mathrm{S}, \mathrm{a}} / V_{\mathrm{S}, \max }$ と $\theta_{\max }$ および $\theta_{\mathrm{ave}}$ の関係

と予想される. すなわち，補強土壁内における $V_{\mathrm{S}}$ の頻 度分布形状の変化を定期的に把握することで補強土壁の 健全性を客観的に判断できる可能性がある.

図－12は，各調査箇所における補強土壁の深度およ び延長方向の $V_{\mathrm{S}}$ の平均值 $V_{\mathrm{S}, \mathrm{a}}$ を $V_{\mathrm{S}}$ の最大值 $V_{\mathrm{S}, \max }$ で除し たパラメータである $V_{\mathrm{S}, \text { ta }} / V_{\mathrm{S}, \max }$ と的的および $\theta_{\mathrm{ave}}$ の関係を 示している. 図ー10に示したように補強土壁内の $V_{\mathrm{S} \text {, max }}$ は，上載圧の影響によって補強土壁の下部で計測される. この補強土壁下部における $V_{\mathrm{S} \text { max }}$ は壁面パネルの変状等 が発生して補強土壁の健全性が低下したとしても，上部 の補強土壁全体の重量の変化は小さいため, $V_{\mathrm{S}, \max }$ の変 化も小さいと予想される，すなわち， $V_{\mathrm{S}, \max }$ は竣工直後 からの補強土壁の状態を評価可能なパラメータの一つで あると解釈することができる。一方， $V_{\mathrm{S}, \mathrm{ta}}$ は補強土壁に 変状が発生し， $V_{\mathrm{S}}$ の局所的な低下領域が発生した場合 には相対的に低下寸るパラメータだと考えられる.この ようなことから， $V_{\mathrm{S}, \text { a }} / V_{\mathrm{S}, \text { max }}$ は健全な補強土壁ほど大き な值となり，変状の程度に忘じて低下するパラメータだ と解釈できる，ここで，図一12を見ると， $\theta_{\max }$ および $\theta_{\mathrm{ave}}$ が小さいほど $V_{\mathrm{S}, \mathrm{a}} / V_{\mathrm{S}, \text { max }}$ は大きい傾向にあり， $V_{\mathrm{S}, \mathrm{a}} / V_{\mathrm{S}}$ ${ }_{\text {max }}$ によって補強土壁の損傷程度を評価できる可能性が ある.しかし，調査箇所(3)のフロットは全体の傾向から 外れており，壁面パネルの変状は小さいが，補強士壁内 部の $V_{\mathrm{S}}$ も小さい場合の健全性の解釈については，更な る検討が必要だと考えている，また，今後は既設補強土 壁のデータを加えるとともに，構築準備中である凍上に よって意図的に変状を与えた実物大補強土壁に対するデ 一タも追加し，図一11や図－12に示した健全性評価手 法の実用性について検討寸る予定である，また，本文で 対象とした補強土壁の多くは供用中の道路盛土であり， ボーリング調査が困難であった。このため，今後の調査 対象とする既設補強土壁では，ボーリングなどの地盤調 査を併用し，本文で検討した評価手法と土質特性の関連 
性を検討する予定である.

\section{4. まとめ}

本研究より得られた主な知見を以下にまとめる.

1) 表面波探査によって変状が進行している補強土壁に おける局所的な $V_{\mathrm{S}}$ の低下領域を把握できた。 また, 地下水位が高くない場合には, 補強土壁と支持地盤 を $V_{\mathrm{S}}$ 分布から明膫に判断できるため, 補強土壁の性 状把握に表面波探查は有用である.

2) 深度方向の $V_{\mathrm{S}}$ の増加傾向は, 変状が少ない補強土壁 では深度とともに $V_{\mathrm{S}}$ は増加する傾向にあるものの, 変状が進行している補強土壁では局所的に $V_{\mathrm{S}}$ が低下 していることを確認できた。このことから，補強土 壁の経時的な健全性変化の評価手法の一つとして, 深さに対する $V_{\mathrm{S}}$ 分布を定期的に把握することが有用 であると考えられる.

3）補強土壁内の $V_{\mathrm{S}}$ の頻度分布から, 壁面パネルの変状 が小さい補強土壁では特定の $V_{\mathrm{S}}$ の相対度数が明確に 大きくなり，さらに正規分布状に $V_{\mathrm{S}}$ が分布する。一 方で，壁面パネルの傾斜角が大きい場合や壁面パネ ルにクラックが発生している場合では，頻度分布に おいて $V_{\mathrm{S}}$ のピークは複数存在し, 正規分布状ではな かった.このことから， $V_{\mathrm{S}}$ の頻度分布における分布 形状の変化と補強土壁の健全性には関連性があり, 分布形状の変化からも補強土壁の経時的な健全性を 把握できる可能性がある.

4) 竣工時から現在までの補強土壁の $V_{\mathrm{S}}$ の変化を間接的 に表すパラメータとして $V_{\mathrm{S}, \mathrm{a}} / V_{\mathrm{S}, \max }$ を導入すると, $V_{\mathrm{S}, \mathrm{a}} / V_{\mathrm{S}, \max }$ は壁面パネル傾斜角の増加とともに低下寸 る傾向にあった.

謝辞 : 本調査の実施にあたり，北見市都市建設部土木課 および道路管理課にご協力頂いた. また, 本研究の一部 は北見土木技術協会の研究助成を受けて実施した. 未筆 ながら記して深甚なる感謝の意を表します。

\section{参考文献}

1) 社会資本整備審議会 道路分科会道路メンテナンス技術小 委員会:道路のメンテナンスサイクルの構築に向けて,2013.

2) 王宗建, 竜田尚希, 服部浩崇, 辻慎一朗, 太田秀樹 : 二 重構造を有する補強土壁の地震後の状況と補修, ジオシ ンセテイックス論文集，Vol.24，pp.125-130，2009.

3) 川尻峻三，涉谷啓，鳥居宣之：ジオテキスタイル補強土 壁の変状メカニズムに関する事例研究, 地盤工学ジャー ナル, Vol.6, No.1, pp.15-25, 2011.

4) 中村洋丈, 横田聖哉, 中澤正典, 竜田尚希, 辻慎一朗 : 泥岩を用いたジオテキスタイル補強土壁の変状事例研究, 地盤工学ジャーナル, Vol.6, No.1, pp.35-51, 2013.

5) Izawa, J. and Kuawano, J. : Evaluation of extent of damage to geogrid reinforced soil walls subjected to earthquakes, Soils and Foundations, Vol. 51,No. 5,pp. 945-958, 2011.

6) Park, C.B., Miller, R.D. and Xia, J. : Multichannel analysis of surface waves, Geophysics, Vol. 64, No.3, pp.800-808,1999.

7) 川尻峻三，川口貴之，鈴木信太朗，台丸谷俊輝，中村大, 山下聡 : 浅層地盤の $\mathrm{S}$ 波速度構造把握に対する表面波探 查の適用性, 第 50 回地盤工学研究発表会概要集(DVDROM), pp. 181-182, 2014.

8) 田中悠睴，川尻峻三，橋本聖，川口貴之，中村大，山下 聡, 山田充, 佐藤厚子 : 締固め条件を変えた試験盛土の 降雨前後に㧫ける $\mathrm{S}$ 波速度分布の変化に関する研究，地 盤工学会北海道支部技術報告集, Vol. 56, pp.329-338, 2016.

9）一般財団法人 土木研究センター: 補強土（テールアル メ）壁工法 設計・施工マニュアル, 第 4 回改訂版, pp.248-250, 2014.

10）竹園 紘樹，三浦みなみ，高橋正和，涉谷啓，川尻峻三： 締固め度及び含水比が土のせん断弾性波速度に与える影 響，地盤工学会北海道支部技術報告集，Vol. 52，pp.329338, 2012.

11）太田裕, 後藤典俊: $\mathrm{S}$ 波速度を他の土質的諸指標から推 定寸る試み, 物理探鉱, Vol.29, No.4, 1976.

\title{
MEASUREMENT AND EVALUATION OF S-WAVE VELOCITY BY THE SURFACE-WAVE METHOD TO EXISTING REINFORCED SOIL WALLS
}

\author{
Akinobu OGASAWARA, Shunzo KAWAJIRI, Hijiri HASHIMOTO, Takayuki \\ KAWAGUCHI, Yuki TANAKA, Dai NAKAMURA and Satoshi YAMASHITA
}

In recent years, it has been reported that the surface-wave method is useful as an efficient way to evaluate the current condition of a reinforced soil wall. In this study, we have applied the surface-wave method to five reinforced soil walls, having different degrees of deformation, in the Okhotsk area of Hokkaido to investigate the relationship between the distribution of $V_{\mathrm{S}}$ and the slope angle of wall panels. The results show that as long as the slope angle is large, $V_{\mathrm{S}}$ reduces locally rather than increasing proportionally to the depth. Accordingly, we find that the use of $V_{\mathrm{S}}$ has the possibility of evaluating the degree of damage to reinforced soil walls.

KEYWORDS: Reinforced soil wall, Stability assessment, S-wave velocity, Wall inclination angle 